Tamara Jovanov Apasieva*

Edo Rajh **

Jelena Budak ${ }^{* * *}$

Ljupčo Davčev ${ }^{* * * *}$
JEL Classification: J24, L26

Preliminary statement

https://doi.org/10.32910/ep.72.2.1

\title{
ENTREPRENEURIAL INTENTIONS OF STUDENTS AT PRIVATE UNIVERSITIES IN TRANSITION ECONOMIES
}

This paper investigates the entrepreneurial potential among students at private universities in two transition countries through the analysis of students' entrepreneurial intentions (EI). Empirical analysis is based on survey data we collected in 2017 and 2018 from over 400 students of economics and business at private universities in North Macedonia and Croatia. The theory of planned behaviour and a set of other antecedents are employed in order to examine the effect of both personal-level and contextual variables on entrepreneurial intentions. Assessing the students' image of an entrepreneur and how they evaluate the entrepreneurs' social and economic roles in society, as well as the prestige of an entrepreneur when compared to other professions, offer valuable inputs for policy makers aiming to improve the entrepreneurial potential and business climate in developing economies. This study provides empirical evidence of the positive effect of two variables

* T. Jovanov Apasieva, PhD, Assistant Professor, The Faculty of Economics, Goce Delcev University in Shtip, (e-mail: tamara.jovanov@ugd.edu.mk)

${ }^{* *}$ E. Rajh, PhD, Senior Research Fellow, The Institute of Economics, Zagreb (e-mail: erajh@ eizg.hr)

**** J. Budak, PhD, Senior Research Fellow, The Institute of Economics, Zagreb, (e-mail: jbudak@eizg.hr)

**** Lj. Davčev, PhD, Assistant Professor, The Faculty of Economics, Goce Delcev University in Shtip, (e-mail: ljupco.davcev@ugd.edu.mk). The paper was received on 25.09.2018. It was accepted for publication on 13.02.2020. 
from the theory of planned behaviour (personal attitude towards entrepreneurship and subjective norm) on entrepreneurial intent of business students at private universities in transition countries. The most striking result of the study is the positive effect of perceived barriers (as a contextual variable) on entrepreneurial intent, a finding that is contrary to past research and literature review.

Keywords: entrepreneurship, entrepreneurial intentions, transition, theory of planned behaviour

\section{INTRODUCTION}

Entrepreneurship is regarded as a factor of critical importance for the socioeconomic development of both transition and non-transition countries (Carree \& Thurik, 2003; Matlay, 2006; Mastura, Rashid \& Aziz, 2008; Cheng, Chan \& Mahmood, 2009; Erken, Donselaar, Thurik, 2016). Throughout the years, we have witnessed various reports and studies elaborating on the benefits of entrepreneurship, such as innovativeness, flexibility, self-employment, and creation of new jobs, even in times of economic recession. The turbulent and striking change of business environment increased the importance of fostering entrepreneurial spirit, and put the topic of motivation to pursue entrepreneurial activities in the spotlight of scientific research (Brazeal \& Herbert, 1999; Lüthje \& Franke, 2003; Kuckertz, 2013; Kuckertz \& Prochotta, 2018).

Greater knowledge of the determinants which influence entrepreneurial behaviour can help in future creation of better, i.e. more focused educational courses and setting up public policies for increased support of entrepreneurship, as well as their evaluation (Storey, 2003). Consequently, many researchers and experts believe it is of great significance to better understand the underlying factors that lead individuals to a path of entrepreneurial career (Kickul, Gundry, Barbosa \& Whitcanack, 2009; Sanches, 2012; Watchravesringkan, Hodges, Yurchisin, Hegland, Karpova, Marcketti \& Yan, 2013; Grilo \& Thurik, 2005; Grilo \& Thurik, 2008; Freytag \& Thurik, 2007; Engle, Dimitriadi, Gavidia, Schlaegel, Delanoe, Alvarado, Buame \& Wolff, 2010; Rajh, Budak, Ateljević, Davčev, Jovanov \& Ognjenović, 2017).

Because of the findings of these studies, we now know that research focused only on entrepreneurial personality factors is insufficient in providing comprehensive understanding of entrepreneurial behaviour, and as a result, attention is being reverted to intentional processes. Entrepreneurial intention (EI) is regarded as an important phenomenon in research of entrepreneurship (Liñán \& Fayolle, 2015). 
Part of the present literature elaborating on entrepreneurial process and entrepreneurial behaviour explains the entrepreneurial outcomes (actual engagement) as a function of the relationship between the organization and the environment, and describes individual intentions as incidental rather than fundamental to organizational outcomes. However, studies also support the hypothesis that entrepreneurial intention of an individual often leads to actual engagement, due to capabilities, motivation, and determination (Jenkins \& Johnson, 1997).

Up to this point, many empirical studies have examined entrepreneurial intention among young people, specifically students from state and/or private universities (see for example Harris \& Gibson (2008) for the U.S., Autio, Keeley, Klofstein, Parker \& Hay (2001) for Scandinavian and U.S students, Veciana, Aponte \& Urbano (2005)). This practice derives from the point of view which places university students in a role of the main source of future entrepreneurs. Their university knowledge of entrepreneurship might shape their inclination to start their own businesses in the future (Wang \& Wong, 2004). However, the results on the relation between education and entrepreneurship are mixed, and while some authors suggest a positive relation (Parker, 2011; Block, Hoogerheide \& Thurik, 2013), others (Blanchflower, 2004; Van Praag, Van Witteloostuijn \& Van Der Sluis, 2009) state that entrepreneurship is negatively associated with education. Nevertheless, nowadays, the concept of the Triple Helix of university-industry-government relationships locates the potential for innovation and economic development in a Knowledge Society (Lowe, 1982; Sábato \& Mackenzi, 1982; Etzkowitz, 1993; Etzkowitz \& Leydesdorff, 1995). It is considered that the hybridisation of elements from university, industry, and government has the potential to create new institutional and social formats for production, transfer, and application of knowledge.

Therefore, we consider it is important to study the intention of students to become entrepreneurs in order to find the antecedents that influence the entrepreneurial intentions of students (from private universities) in transition countries. Furthermore, we seek to provide a plausible answer to the question "How to cultivate entrepreneurial intention among university students?", and to see if changes are more urgent in the educational system, the industry itself, or in governmental policies on entrepreneurship.

Previous research provides clear indications of differences in entrepreneurial intent and engagement between developed and developing countries dependent on the vitality of the economic situation and risk-perceiving behaviours (Iakovleva, Kolvereid \& Stephan, 2011). These studies suggest that entrepreneurial intentions are stronger among respondents from developing countries. Our previous research on entrepreneurial intentions among public university students in South East European (SEE) countries showed the country context is important because it leads to the different levels of EI achieved, in particular among transition coun- 
tries (North Macedonia and Croatia). This subject, although in a different manner, has been tackled in the GEM Reports for these countries ${ }^{1}$, which provide some additional information about entrepreneurial intention and actual entrepreneurial engagement. According to the reports, North Macedonia shows a higher percentage of the population with entrepreneurial intent (29\%), but a lower percentage of early-stage entrepreneurial activity (6.6\%), in contrast to Croatia which demonstrates a lower percentage of entrepreneurial intention (20\%), but a higher percentage of early-stage entrepreneurial activity (8\%).

The next section presents literature review, followed by the description of the model and the hypotheses. Methodology is described in the fourth section, and the results are discussed in section five. The final section includes conclusions and policy implications, pointing to some limitations and lines for future research.

\section{LITERATURE REVIEW}

After the ground-breaking works by Shapero (1984) and Shapero and Sokol (1982), the entrepreneurial intention framework has been the base for a number of studies (Krueger, Reilly \& Carsrud, 2000; Lüthje \& Franke, 2003; Veciana et al., 2005; De Pillis \& Reardon, 2007; Lee, Wong, Foo \& Leung, 2011; Liñán \& Fayolle, 2015). Also, its framework has been integrated with theories from the field of social psychology (Ajzen, 1991; Bandura, 1982).

Even though human behaviour can be a result of unconscious and unintended factors of influence, the main interest in studying entrepreneurial intention is a conscious and intended act (Bird, 1988). A significant part of the entrepreneurial process is the intentional identification of opportunity, which means that individual entrepreneurial intention is worthy of attention in entrepreneurship research (Gartner, Shaver, Gatewood \& Katz, 1994; Kritiansen \& Indarti, 2004). Moreover, entrepreneurial intention can be considered a first step in the evolving and longterm entrepreneurial process that occurs over time (Crant, 1996).

The necessity to create better policies for nurturing entrepreneurship and improving educational curriculums brings us to the essential research questions about entrepreneurial potential of countries, and the main drivers that lead individuals on the path of becoming entrepreneurs (Shane \& Venkataraman, 2000). In the last few decades, the research of entrepreneurship intention has been in the spotlight, and one of the main concerns of entrepreneurship researchers and educators (Lope Pihie \& Bagheri, 2009; De Clercq, Benson \& Martin, 2012). This is

\footnotetext{
1 See the last available GEM Reports for Macedonia (2013) and Croatia (2016).
} 
so due to the fact that intentions have been proven to help in predicting one's choice of vocation and entrepreneurial plans (Kickul et al., 2009; Carsrud \& Brännback, 2009), as well as their actual (real) involvement in entrepreneurial activities (Verheul, Thurik, Grilo \& Zwan, 2012). Furthermore, research has proven that intentions are connected to actual behaviour through the goals that individuals' set, as well as the effort and commitment they make in achieving those goals (Carsrud \& Brännback, 2009). Studies show a high probability for becoming an actual entrepreneur, as well as for a new venture creation, when a clear entrepreneurial intention has been found to exist (Pfeifer, Šarlija \& Zekić Sušac, 2016). Some authors find that the existence of a potential for entrepreneurship in communities or in large organizations (intrapreneurship) is crucial for actual entrepreneurship (Krueger \& Brazeal, 1994).

Entrepreneurial behaviour is considered to be a deliberate intentional behaviour (Bird, 1988), i.e. a function of identification of opportunity, process of thinking and planning, and therefore also appropriate for intention models (Krueger, 1993). Entrepreneurial intentions are considered important for better understanding of entrepreneurial behaviour in the process of discovering, creating and exploiting opportunities (Gartner et al., 1994). They can be explained as mental orientations, such as desire, wish, and hope, which influence an individual's choice of career in entrepreneurship (Peng, Lu \& Kang, 2012). Intentions are seen as the single best indicator of actual behaviour (Ajzen, 1991; Kolvereid 1996; Krueger et al., 2000), especially when we discuss behaviour that is hard to observe, or when it involves unpredictable time lags (Krueger et al., 2000).

Vast research has been conducted to explore the effects of various personallevel variables on entrepreneurial intention (Lee \& Wong, 2004; Segal, Borgia \& Schoenfeld, 2005; Liñán \& Santos, 2007). Numerous phenomena such as demographics, personal traits, and psychological variables, as well as prior entrepreneurial exposure and social capital, were analysed as the antecedents of entrepreneurial intention. Another stream of research is focused on explaining the effect of various contextual variables, such as national, regional or cultural variables, as the antecedents of entrepreneurial intention (Veciana et al., 2005; Freytag \& Thurik, 2007; Engle et al., 2010).

Some studies (Grilo \& Thurik, 2005; Grilo \& Thurik, 2008) focus on explaining the engagement levels of entrepreneurial activity (the entrepreneurial ladder) using demographic variables (such as gender, age, education level, whether parents are self-employed), country specific effects (such as the current economic climate), measures of risk tolerance, internal and external locus of control, and perceptions of obstacles (such as administrative complexities, availability of financial support, accessibility of information for start-ups). Additional research is also done in the context of understanding and prediction of entrepreneurial behaviour of early-stage entrepreneurs and intrapreneurs (Dézsi-Benyovszki \& Szabó, 2017). 
Other studies also focus on theoretical and methodological issues of the entrepreneurial intention model (Liñán \& Chen, 2009; Schlaegel \& Koenig, 2014).

So far, academic research has presented several motivational theories that are helpful in understanding different factors that shape entrepreneurial career intention. One of the most used theoretical models of entrepreneurial intention is the theory of planned behaviour (TPB) developed by Ajzen (1991). It is a framework to be applied in different behavioural contexts, and first used in the entrepreneurial intention context by Krueger and Carsrud (1993). According to this model, individuals' intentions to adopt a specific behaviour, such as students' intentions to start their own businesses, is a cognitive process, and an outcome of the interaction between three different factors (variables) that affect the entrepreneurial intention: attitude towards the entrepreneurship (if students consider the option of entrepreneurship and its consequences as favourable or unfavourable), subjective norm (the support and value that students get from their close environment, like family, friends, and community, and the extent to which they rely on that support and comply with those values), and perceived behavioural control (perceived selfefficacy in performing the required tasks to set up and manage a new business). Previous research provided empirical evidence for the significant influence of all three factors on students' entrepreneurial intentions (Zhao, Seibert \& Hills, 2005; Harris \& Gibson, 2008; Liñán, 2008; Watchravesringkan et al., 2013).

Ajzen's model of planned behaviour appeared to be an effective predictor of different behaviours (risk - oriented behaviour, ethical behaviour, the intent to start one's own business) in a number of studies in social sciences. The average correlation between behavioural intent and targeted behaviour in these studies was 0.73 , which indicates a statistically significant connection among the tested variables (Engle et al. 2010). Krueger et al. (2000) have stated that intention-based models resulting from the TPB imply that entrepreneurial intentions are a function of the perceived possibility and the perceived appeal of the entrepreneurial act. Dézsi-Benyovszki and Szabó (2017) found that the TPB is also successful in predicting the entrepreneurial behaviour of early-stage entrepreneurs, as well as that of intrapreneurs. The TPB is one of the most used theoretical frameworks for studying entrepreneurial intention and behaviour (Fayolle, Gailly \& LassasClewrc, 2006; Zellweger, Sieger \& Halter, 2011). Additionally, there have also been efforts to extend and develop new theoretical models of entrepreneurial intention (Davidsson, 1995; Krueger et al., 2000; Elfving, Brännback \& Carsrud, 2009), and to integrate them into a single, coherent model (Liñán, Rodríguez-Cohard \& Rueda-Cantuche, 2005; Shook \& Bratianu, 2010; Schlaegel \& Koenig, 2014; Langer, Alfirević, Pavičić \& Krneta, 2016).

Nevertheless, the theory of planned behaviour has been shown as consistent in predicting entrepreneurial intentions (Krueger et al., 2000; Engle et al., 2010; Iakovleva et al., 2011). Several studies suggest that this model can also be used to 
predict entrepreneurial intent on international level (Kolvereid, 1996; Krueger et al, 2000; Autio et al., 2001). Furthermore, scholars argue that personal, but also environmental factors, as well as the combination of both, affect (students') entrepreneurial intentions (Zhao et al., 2005; Kickul, 2009).

The main goal of academic research of entrepreneurial intentions is to identify additional antecedents of entrepreneurial intention. Antecedents vary from different personal-level variables to specific contextual variables. Namely, support and barriers as specific contextual variables, and risk-taking propensity and locus of control as personality variables are also added to the model (Lüthje \& Franke, 2003). Other researchers (De Pillis \& Reardon, 2007) studied the effects of cultural contextual variables operationalized as face-to-face and mass media persuasion about entrepreneurship. Crant (1996) explored the effects of proactive personality and demographics on entrepreneurial intention. Segal et al. (2005) included risk perception into their analysis of entrepreneurial intentions, while Carr and Sequeira (2007), and Peng et al. (2012) included prior entrepreneurial experience (personal and/or family).

Contextual environment is found to be strongly associated with entrepreneurial intention, which results in numerous studies trying to explain the differences in entrepreneurial intention among different countries, regions, and cultural groups. Veciana et al. (2005) have focused on the effect of different economic models when they compared entrepreneurial intentions between Catalonia and Puerto Rico, which also share mutual cultural tradition. Kristiansen and Indarti (2004) placed their attention to the effect of different cultural traditions and economic models, by conducting a comparison between Norway and Indonesia. Engle et al. (2010) conducted an analysis of entrepreneurial intention among 12 countries representing 10 regional cultural clusters, while Iakovleva et al. (2011) conducted a comparison among 13 countries focusing on the differences between developed and developing countries. However, entrepreneurial intentions in European transition countries are still rather underexplored. Rajh et al. (2017) employed Ajzen's model of planned behaviour in their study on differences in entrepreneurial intention among business students at public universities in four South East European countries (Croatia, Bosnia and Herzegovina, Serbia, and North Macedonia), and Macura, Konda and Končar (2015) explored entrepreneurial intentions of students in Bosnia and Herzegovina. A recent study conducted on students in Slovenia showed that personal attitudes towards entrepreneurship, subjective norms, and perceived behavioural control are positively related to individual entrepreneurial intentions (Pejić Bach, Aleksić and Merkač-Skok, 2018). The importance of entrepreneurial intentions has been recognized in past research for Croatia as well. Namely, Langer et al. (2016) performed a longitudinal study at a sample of Croatian public university student cohort in 2011 and in 2014. The results showed the perceived desirability of an entrepreneurial career was somewhat lower in 2014, while perceptions of social support for entrepreneurship increased. Their results did not support the per- 
ceptions of poor entrepreneurial social climate in Croatia, and students evaluated their entrepreneurial careers as a desirable choice. This is in line with the study of Pfeifer et al. (2016), indicating the main predictors of the entrepreneurial intentions in Croatia are entrepreneurial identity aspiration and self-efficacy. However, this might not equally apply for male and female students, since gender differences were observed in Dabić, Daim, Baryaktaroglu, Novak \& Bašić (2016) comparative study of ten countries including Croatia. Aggregate results indicated that female students were less willing to engage in their own businesses, hence no specific evidence was presented at a country level. Morić Milovanović, Srhoj \& Krišto (2015a) and Morić Milovanović, Krišto \& Srhoj (2015b) found differences between female and male students in formation of attitudes towards entrepreneurial careers and entrepreneurial intentions. Entrepreneurial knowledge, independence motive, and social norms were important for female students' attitudes, while locus of control and entrepreneurial skills determined attitudes towards entrepreneurship of male students in Croatia. Kedmenec, Rebernik \& Perić (2015) explored entrepreneurial intentions in regard to social entrepreneurship among students of graduate entrepreneurship programs in Croatia.

Entrepreneurial intentions are a subject of, although scarce, yet relevant scientific research in North Macedonia as well. Namely, Debarliev, Janeska-Iliev, Bozhinovska \& Ilieva (2015) suggest that the three motivational factors which construct the model of TPB (personal attitude, perceived behavioural control, and subjective norm) have a positive impact on entrepreneurial intentions of business students in North Macedonia. They present empirical evidence of the importance and influence of social and cultural factors on entrepreneurial intention in North Macedonia, but state that there is a lack of positive impact of knowing other entrepreneurs, as a supportive factor for entrepreneurial intention. However, they also put a certain doubt about the role of education and supportive university environment in encouraging the entrepreneurial intention, and propose that the support coming from the government and wider external context is not relevant in shaping entrepreneurial intention in North Macedonia. This study, as some studies in the case of Croatia, found that gender has a significant impact on EI, i.e. that being male increases the perceived importance of entrepreneurial intention. This is supported by other research where, for example, Liñán, Santos \& Fernández (2011) found that males are 1.846 times more likely to declare a positive entrepreneurial intention than females (odds ratio).

Tomovska Misoska, Dimitrova \& Mrsik (2016) also suggest that the determinants that form the model of TPB have a significant and positive effect on EI of students in North Macedonia, but they additionally point out that educational experiences and knowledge about entrepreneurship have a statistically significant influence on subjective norms, attitudes towards behaviour, and perceived behavioural control, thus opposing the findings from the previously mentioned study. 
Their results also show a significant influence of perception of business climate towards attitude and perceived behavioural control. Furthermore, Kedmenec, Oreški, Vuković, Postolov \& Jovanovski (2017) found that North Macedonian business students, who have a positive attitude towards entrepreneurship, a supportive subjective norm, and perceive entrepreneurship as controllable behaviour, also have a high probability of having entrepreneurial intentions. In addition, they show that the knowledge about the entrepreneurial environment lowers this probability, which, however, still remains very high.

The common feature of studies of Croatia and North Macedonia is that they develop and employ different models based on the theory of planned behaviour together with additional variables included, so a direct comparison of the results is not possible. However, there is a body of knowledge on entrepreneurial attitudes and potential of Croatian and North Macedonian students to be advanced by this research.

We fill the gap by providing a comparative study of entrepreneurial intent on a sample of business students from private universities in two transition countries, North Macedonia and Croatia. Both countries are ex-Yugoslav republics, belong to the same Balkan region, and have differences in economic models. However, research has shown that they still share similar issues regarding the business climate and the economy in general (the World Bank, 2016) ${ }^{2}$. Namely, one of the main issues in both of these countries is the high unemployment rate of young people, as well as the preference of youth to work in public institutions or large organizations rather than pursue a career in entrepreneurship (Obadić, 2017). We believe it is of importance to find out more about the intents of business students at private universities in these countries in order to tap into the key factors of influence that shape their intents. Although in the two observed countries the majority of business students attend public universities, the observed group of private university students is considered the important source of potential entrepreneurs in future.

\section{METHODOLOGY AND HYPOTHESES}

Our model developed on the basis of the theory of planned behaviour is extended with additional personality variables (such as locus of control and risk-taking propensity), and contextual variables (such as perceived barriers and perceived support factors). Additionally, we study the effects of specific national environments in terms of social, cultural, and economic aspects of a transitional economy from South East Europe on entrepreneurial intention. It is presented in Figure 1.

\footnotetext{
2 See Doing Business Reports for these countries.
} 
Figure 1.

CONCEPTUAL MODEL

\begin{tabular}{|c|c|c|}
\hline Attitude towards entrepreneurship & [H1] & \\
\hline Subjective norm & [H2] & \\
\hline Perceived behavioural control & [H3] & \\
\hline Locus of control & [H4] & Entrepreneurial \\
\hline Risk taking propensity & [H5] & Intention \\
\hline Perceived support factors & [H6] & \\
\hline Perceived barriers & [H7] & \\
\hline
\end{tabular}

Source: Authors

The theory of planned behaviour consists of three basic antecedent variables of entrepreneurial intention: personal attitude towards entrepreneurship, subjective norm, and perceived behavioural control (Ajzen, 1991). The degree to which an individual holds a positive or negative personal valuation about being an entrepreneur refers to the variable personal attitude towards entrepreneurship (Ajzen, 2001; Liñán \& Chen, 2009). Subjective norm can be explained as the perceived social pressure to carry out, or not to carry out entrepreneurial behaviour. More closely, it refers to the perception that "reference people" would approve and give support to the decision to become an entrepreneur, or not (Ajzen, 2001; Liñán \& Chen, 2009). Additionally, the perception of the ease or difficulty of becoming an entrepreneur stands for perceived behavioural control (Liñán \& Chen, 2009).

These three variables, which explain the perceptions of an individual, are considered to be the key predictors of intention in any behavioural context, not just an entrepreneurial one (Ajzen, 1991; Krueger \& Carsrud, 1993).

When we look into the numerous studies that have tested this model in various settings, we find somewhat conflicting results. Krueger et al. (2000) found empirical evidence for a positive association between personal attitude towards entrepreneurship and perceived behavioural control on one hand, and entrepreneurial intention on the other, but no empirical evidence was found for the effect of subjective norm on entrepreneurial intention. Autio et al. (2001) also could not confirm the positive relationship between subjective norm and entrepreneurial intention. According to Dézsiand-Benyovszki and Szabó (2017), there is a significant 
positive effect of personal attitude towards entrepreneurship and perceived behavioural control for early-stage entrepreneurial and intrapreneurial behaviour, while subjective norm has no significant influence on the probability of becoming an early-stage entrepreneur, but has a significant negative influence on the probability of becoming an intrapreneur. Nevertheless, several studies have found evidence for a positive relationship between all three basic antecedent variables and entrepreneurial intention (Kolvereid, 1996; Tkachev \& Kolvereid, 1999; Kolvereid \& Isaksen, 2006; Rajh et al., 2017).

Our model also includes two additional personal - level variables, namely locus of control and risk-taking propensity. They may help explore how personality differences affect entrepreneurial intention. Some studies provide the evidence of the existence of a positive relationship between these two variables and entrepreneurship and entrepreneurial intention (Brockhaus, 1980; Brockhaus, 1987; Bonnett \& Furnham, 1991; Hisrich \& Peters, 1995; Lüthje \& Franke, 2003). Locus of control is defined as the degree to which individuals believe that they have control over the outcomes of events in their lives (Rotter 1966; Lumpkin 1985). Risk taking propensity is the tendency of an individual to engage in activities that are perceived as risky (Brockhaus,1980; Lüthje \& Franke, 2003).

Considerable research also examines cross-country comparisons of entrepreneurial intentions and their antecedents. The studies range from two-country comparisons (Kristiansen \& Indarti, 2004; Veciana et al., 2005) to large multi-country comparisons (Engle et al., 2010; Iakovleva et al., 2011). There is strong empirical evidence that entrepreneurial intention differs between various countries, which may be explained by differences in economic, social and cultural environments. Therefore, we also add contextual aggregate variables as another set of variables to our model. We include two variables that can be regarded as proxies for economic, social, and cultural contexts: perceived support factors and perceived barriers, initially developed by Lüthje and Franke (2003). The existing literature recognizes the importance of social, cultural, institutional, and economic contextual variables for the entrepreneurial intention formation process at the individual level. Previous studies have explored the effects of contextual variables such as attitudes towards entrepreneurship in society, availability of business incubators, funding, content of mass-media, and face-to-face communication about entrepreneurship (Shapero, 1984; Hisrich \& Peters, 1995; Pennings \& Kimberly, 1997; Lüthje \& Franke, 2003; De Pillis \& Reardon, 2007). These factors have been found to have strong positive relationship with entrepreneurial activities.

Therefore, the following hypotheses are proposed:

H1: Personal attitude towards entrepreneurship is positively associated with entrepreneurial intention.

$\mathrm{H} 2$ : Subjective norm is positively associated with entrepreneurial intention. 
H3: Perceived behavioural control is positively associated with entrepreneurial intention.

H4: Locus of control is positively associated with entrepreneurial intention.

H5: Risk taking propensity is positively associated with entrepreneurial intention.

H6: Perceived support factors are positively associated with entrepreneurial intention.

H7: Perceived barriers are negatively associated with entrepreneurial intention.

Data were collected during 2017 and 2018 by using a paper-and-pencil selfadministered survey. The survey was conducted in two countries: North Macedonia and Croatia. The sample consists of 444 students of economics and business from private higher education institutions. The sample is constructed with the convenience sampling technique and it includes students that were present at the lecture when the survey was conducted. The summary statistics of sampled respondents is presented in Table 1.

\section{Table 1.}

SUMMARY STATISTICS OF SAMPLED RESPONDENTS, N = 444

\begin{tabular}{|l|r|}
\hline & \multicolumn{1}{|c|}{$\%$} \\
\hline Gender & \\
\hline Male & 55.2 \\
\hline Female & 43.5 \\
\hline No answer & 1.4 \\
\hline Age & 72.7 \\
\hline $18-20$ & 16.9 \\
\hline $21-23$ & 7.7 \\
\hline $24+$ & 2.7 \\
\hline No answer & \\
\hline Year of study & 40.5 \\
\hline $1^{\text {st }}$ & 33.6 \\
\hline $2^{\text {nd }}$ & 4.8 \\
\hline $3^{\text {rd }}$ & 13.1 \\
\hline $4^{\text {th }}$ & 6.1 \\
\hline 5 th & 2.0 \\
\hline No answer & \\
\hline Country & 26.1 \\
\hline Croatia & 73.9 \\
\hline North Macedonia & \\
\hline
\end{tabular}

Source: Authors 
We used a sample of business students in private universities for several reasons. First, university students studying business programs are at the age and in the process of acquiring and developing their basic knowledge as well as their skills on entrepreneurship that are considered necessary to perform the required tasks and roles for establishing their own businesses (Kickul et al. 2009). Examining the different personality - related and contextual variables that shape their entrepreneurial intentions enables us to tackle the underlying conditions that influence their specific behaviour required for making a decision to become an entrepreneur. The research of entrepreneurial intention among university students as a homogenous group, with regard to the factors such as previous work and business experience, can help us understand the origins of the differences in their entrepreneurial intentions, and consequently design educational curriculums that could enhance their entrepreneurial skills and intentions. Private universities, where the tuition for studying is tenfold higher than the expenses for studying in public universities, are mainly chosen by students from wealthier families, whose parents are well educated, entrepreneurs or managers in large organizations (Lilek, 2015; Jurasić, 2016). We believe that the microenvironment of these students might also have an effect on their entrepreneurial intents, due to the knowledge, information, and/or experience of the people from their reference group, i.e. their closest family or friends.

Research instrument applied in our study was a highly structured questionnaire that included a set of multi-item scales previously developed by other researchers and published in relevant literature (Appendix). Items were measured on a five-point Likert-type scale, anchored at 1 (strongly disagree) and 5 (strongly agree). The following scales were included in the questionnaire: locus of control, risk taking propensity, perceived barriers, perceived support factors, personal attitude towards entrepreneurship, perceived behavioural control, subjective norm, and entrepreneurial intention. Scale for locus of control was taken from Lumpkin (1985), scales for risk taking propensity, perceived barriers, and perceived support factors were taken from Lüthje and Franke (2003), and scales for personal attitude towards entrepreneurship, perceived behavioural control, subjective norm, and entrepreneurial intention were taken from Liñán and Chen (2009).

Collected data were first analysed with exploratory and confirmatory factor analysis in order to assess the validity of the applied measurement scales. Initial exploratory analysis with varimax raw rotation of factors was performed on the entire pool of 35 items. 14 items were removed from further analysis - items with low factor loadings on their primary factor, and items with high factor loadings on more than one factor. One entire scale was removed from further analysis during that procedure - perceived behavioural control scale. The remaining items were again factor analysed and they loaded on seven factors. Principal components analysis was employed to extract the factors. The Kaiser-Guttman rule was used to determine the number of factors to extract. 
After exploratory factor analysis, 21 items were subjected to confirmatory factor analysis to conduct more rigorous evaluation of underlying factor structure and the validity of measurement scales.

Multiple regression analysis was conducted to test the hypotheses. Entrepreneurial intention is specified as a dependent variable, and locus of control, risk taking propensity, perceived barriers, perceived support factors, personal attitude towards entrepreneurship, subjective norm, and country, as independent variables. The tolerance measures were checked to detect possible multicollinearity. Since the values of tolerance were between 0.83 and 0.94 , it was safe to conclude that multicollinearity did not exist (Kutner et al., 2004). Data analysis was conducted with a software package Statistica 12.

\section{RESULTS AND DISCUSSION}

Initial exploratory factor analysis resulted in the removal of 14 items with low factor loadings on their primary factor and high cross-loadings. Final exploratory factor analysis resulted in factor solution with seven factors, where each item had a high factor loading on their primary factor (Figure 2). The seven-factor solution explained $70.1 \%$ of the variance.

Figure 2.

EXPLORATORY FACTOR ANALYSIS - SCREE PLOT

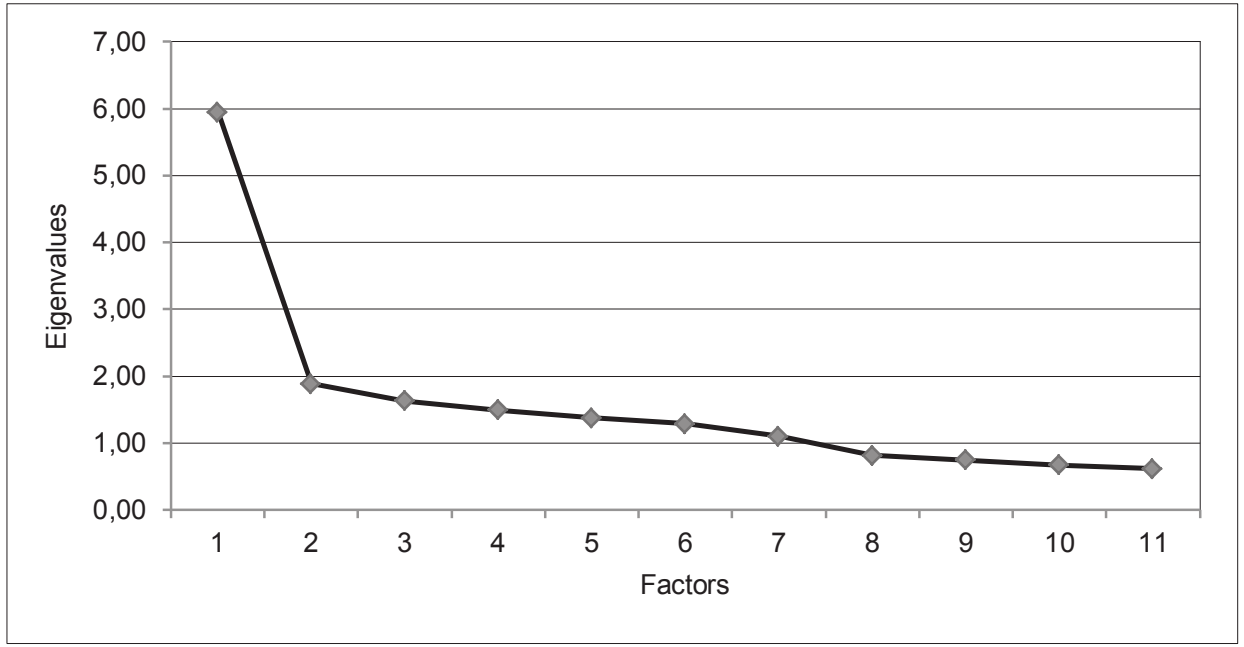

Source: Authors 
T. JOVANOV APASIEVA, E. RAJH, J. BUDAK, LJ. DAVČEV: Entrepreneurial intentions of students at private... EKONOMSKI PREGLED, 72 (2) 157-184 (2021)

The seven-factor solution was additionally tested with confirmatory factor analysis. Fit indices indicate an acceptable level of fit for specified measurement model, and all factor loadings were significant at $\mathrm{p}<0.01$ level (Table 2). The results of exploratory and confirmatory factor analyses indicate that applied measurement scales exhibit an acceptable level of validity.

\section{Table 2.}

\section{EXPLORATORY AND CONFIRMATORY FACTOR ANALYSIS RESULTS}

\begin{tabular}{|c|c|c|}
\hline Items & EFA factor loadings & CFA factor loadings \\
\hline \multicolumn{3}{|c|}{ Locus of Control } \\
\hline i5 & 0.82 & $0.35^{*}$ \\
\hline i6 & 0.78 & $1.12^{*}$ \\
\hline \multicolumn{3}{|c|}{ Risk Taking Propensity } \\
\hline i7 & 0.84 & $0.50^{*}$ \\
\hline i8 & 0.76 & $0.80^{*}$ \\
\hline \multicolumn{3}{|c|}{ Perceived Barriers } \\
\hline i10 & 0.78 & $0.47 *$ \\
\hline i11 & 0.80 & $0.72 *$ \\
\hline \multicolumn{3}{|c|}{ Perceived Support Factors } \\
\hline i14 & 0.77 & $0.98 *$ \\
\hline i15 & 0.78 & $0.34 *$ \\
\hline \multicolumn{3}{|c|}{ Personal Attitude toward Entrepreneurship } \\
\hline i16 & 0.78 & $0.48^{*}$ \\
\hline i17 & 0.73 & $0.75^{*}$ \\
\hline i18 & 0.70 & $0.74 *$ \\
\hline i19 & 0.69 & $0.85^{*}$ \\
\hline \multicolumn{3}{|c|}{ Entrepreneurial Intention } \\
\hline i27 & 0.69 & $0.76^{*}$ \\
\hline $\mathrm{i} 28$ & 0.79 & $0.91 *$ \\
\hline i29 & 0.83 & $0.85^{*}$ \\
\hline $\mathrm{i} 30$ & 0.87 & $0.99 *$ \\
\hline $\mathrm{i} 31$ & 0.83 & $0.96^{*}$ \\
\hline $\mathrm{i} 32$ & 0.72 & $0.84 *$ \\
\hline \multicolumn{3}{|c|}{ Subjective Norm } \\
\hline i33 & 0.79 & $0.62 *$ \\
\hline i34 & 0.90 & $0.88^{*}$ \\
\hline i35 & 0.85 & $0.81 *$ \\
\hline
\end{tabular}

Source: Authors. Note: $\mathrm{CFA}$ fit indices: $\mathrm{GFI}=0.88, \mathrm{AGFI}=0.83 ; \mathrm{NFI}=0.83 ; \mathrm{NNFI}=0.83 ; \mathrm{CFI}=$ 0.87 ;MSEA $=0.08 *$ Factor loadings significant at $\mathrm{p}<0.01$ level 
The results of multiple regression analysis (Table 3) indicate that Entrepreneurial Intention was significantly and positively affected by personal attitude towards entrepreneurship $(\beta=0.41)$, subjective norm $(\beta=0.23)$, and perceived barriers $(\beta=0.11)$.

The results support hypotheses $\mathrm{H} 1$ and $\mathrm{H} 2$. However, hypotheses H4, H5, H6, $\mathrm{H} 7$, and $\mathrm{H} 8$ are rejected. Hypothesis $\mathrm{H} 3$ could not be tested in this study because of the results of factor analysis.

Table 3.

\section{REGRESSION ANALYSIS - DEPENDENT VARIABLE: ENTREPRENEURIAL INTENTION}

\begin{tabular}{|l|c|c|c|c|c|c|}
\hline \multicolumn{1}{|c|}{$\begin{array}{c}\text { Independent } \\
\text { variables }\end{array}$} & $\begin{array}{c}\text { Standardized } \\
\text { coefficients }(\beta)\end{array}$ & $\begin{array}{c}\text { Standard } \\
\text { error }\end{array}$ & $\begin{array}{c}\text { Unstandardized } \\
\text { coefficients (B) }\end{array}$ & $\begin{array}{c}\text { Standard } \\
\text { error }\end{array}$ & t-value & p-value \\
\hline Intercept & & & -0.08 & 0.35 & -0.24 & 0.81 \\
\hline Locus of Control & -0.01 & 0.04 & -0.01 & 0.04 & -0.17 & 0.87 \\
\hline $\begin{array}{l}\text { Risk Taking } \\
\text { Propensity }\end{array}$ & 0.01 & 0.04 & 0.01 & 0.05 & 0.20 & 0.84 \\
\hline Perceived Barriers & 0.11 & 0.04 & 0.13 & 0.05 & 2.62 & 0.01 \\
\hline $\begin{array}{l}\text { Perceived Support } \\
\text { Factors }\end{array}$ & 0.01 & 0.04 & 0.01 & 0.04 & 0.30 & 0.77 \\
\hline $\begin{array}{l}\text { Personal } \\
\text { Attitude towards } \\
\text { Entrepreneurship }\end{array}$ & 0.41 & 0.04 & 0.49 & 0.05 & 9.30 & 0.00 \\
\hline Subjective Norm & 0.23 & 0.04 & 0.26 & 0.05 & 5.08 & 0.00 \\
\hline Country & 0.04 & 0.04 & 0.08 & 0.10 & 0.85 & 0.40 \\
\hline
\end{tabular}

Source: Authors. Model fit: R2 $=0.32$; adjusted R2 $=0.31 ;$ F-value $=27.32 ; \mathrm{p}=0.00$

\section{CONCLUSIONS}

The purpose of this empirical study was to understand the determinants of entrepreneurial intentions of business students at private universities in two South East European countries. A comparative analysis of entrepreneurial intentions between two transition countries in the region, and investigating the effects of perceptions, personal-level and contextual variables on entrepreneurial intention, is considered a novelty in this field. The basic model of planned behaviour is ex- 
tended with locus of control, risk-taking propensity, perceived barriers and perceived support factors.

The comparative analysis of private universities students of economics and business in Croatia and North Macedonia yielded some interesting findings. Namely, our study provides empirical evidence of the positive effect of two variables from the theory of planned behaviour, and one contextual variable on entrepreneurial intent of students from private universities in two transition economies. Specifically, business students at private universities in these countries place a rather positive personal valuation to being an entrepreneur, and thus personal attitude towards entrepreneurship has a significant and positive association with entrepreneurial intent. These findings are in line with past research (Kolvereid, 1996; Tkachev \& Kolvereid, 1999; Krueger et al., 2000; Kolvereid \& Isaksen, 2006; Rajh et al., 2017; Pejić Bach et al., 2018).

Contrary to some previous research (Krueger et al., 2000; Autio et al., 2001), our study also shows a positive effect of subjective norm on entrepreneurial intent. As the same stands for students' entrepreneurial intentions in Slovenia (Pejić Bach et al., 2018), this indicates that the support of relevant people is important across the region and has an important influence on one's intent of becoming an entrepreneur to the point where it can very well encourage it.

One of the most striking results was that, contrary to the existing literature, we found empirical evidence that perceived barriers as a contextual variable have a significant and positive association with entrepreneurial intent. One would usually think that barriers ought to hinder the intent to become an entrepreneur, but here just the opposite is the case. However, having in mind that many students from private universities come from families where parents are well educated, have careers as entrepreneurs, or are managers in large organizations, we might assume that in such microenvironment, a person may be better informed and more aware of the existing barriers and of the ways to minimise their potentially negative effects on business, which could, as a result, reverse their negative association with EI.

However, one has to have in mind that in North Macedonia, as well as in Croatia, private universities lack a long tradition and reputation, as it is the case in the U.S., where top-ranked universities are private ones. We do not provide any empirical evidence that students from wealthier families in Croatia and North Macedonia, who enrol in private business schools, will become successful entrepreneurs, and this remains to be explored in the future.

Given the scope of our research, focus on the business students at private universities limits the extension of our conclusions. However, it suggests that education could help in creating a beneficial climate for fostering entrepreneurial intentions. Erzsébet (2004) also provides evidence for the crucial importance of entrepreneurial education and training in the development and strengthening of 
an entrepreneurial society. This could mean that, in order to boost entrepreneurial intention, policymakers would be well advised to pay more attention to developing strategies for promotion and education for entrepreneurship on all levels in schools and universities, as well as promotion of entrepreneurship aimed at a more general public. This study expands our understanding of what drives the entrepreneurial intention in transition countries.

Lines for future research should attempt to compare EI among students from private and public universities in these countries (and among transition and nontransition economies), as well as students from technical universities. Furthermore, an additional research question whether the respondents belong to an entrepreneurial family or whether they are already involved in entrepreneurship should be included in the model in order to understand the key determinants that influence them in developing their entrepreneurial projects. It could also be interesting to explore the connection between the independent variables and/or to try testing for a non-linear connection between the independent and the dependent variable. In some of the next steps, one might even try to assess the citizens' points of view and their EI, so the results could be extended to the general population. Throughout our study, we used a framework where entrepreneurial intention was the variable 'to be explained'. We are aware that many reversed causalities may occur regarding our 'independent' variables, but given our cross-sectional approach, we do very little to tackle this.

Acknowledgments: Ljupčo Davčev and Tamara Jovanov Apasieva acknowledge the financial support from University "Goce Delcev" - Shtip (research project No. 0307-98/102 and No. 0201-545/9 "Analysis of entrepreneurial potential with a focus on entrepreneurial intentions of young people in developing countries"). All authors express their gratitude to colleagues and students who participated in the survey.

\section{REFERENCES}

1. Ajzen, I. (1991). The theory of planned behaviour. Organizational Behavior and Human Decision Processes, 50(2): 179-211.

2. Ajzen, I. (2001). Nature and operations of attitude. Annual Review of Psycho$\log y, 52: 27-58$.

3. Autio, E., Keeley, R.H., Klofsten, M., Parker, G.G.C., Hay, M. (2001). “Entrepreneurial intent among students in Scandinavia and in the USA", Enterprise and Innovation Management Studies, (2), 2: 145-160. 
T. JOVANOV APASIEVA, E. RAJH, J. BUDAK, LJ. DAVČEV: Entrepreneurial intentions of students at private... EKONOMSKI PREGLED, 72 (2) 157-184 (2021)

4. Bandura, A. (1982). Self-efficacy mechanism in human agency. American Psychologist, 37(2): 122-147.

5. Bird, B.J. (1988). Implementing entrepreneurial ideas: The case for intention. Academy of Management Review, 13(3): 442-453.

6. Blanchfl ower, D. G. (2004). Self-Employment: More may not Be Better. NBER Working Paper, No. 10286.

7. Block, J. H., Hoogerheide, L., Thurik, R. (2013). Education and Entrepreneurial Choice: An Instrumental Variables Analysis. International Small Business Journal, 31(1): 23-33.

8. Bonnett, C., Furnham, A. (1991). Who wants to be an entrepreneur? A study of adolescents interested in a young enterprise scheme. Journal of Economic Psychology, 12(3): 465-478.

9. Brännback, M., Carsrud, A. (2009). Cognitive Maps in Entrepreneurship: Researching Sense Making and Action. In: Carsrud, A., Brännback, M. (eds.): Understanding the entrepreneurial mind: Opening the black box. Heidelberg: Springer, 75-96.

10. Brazeal, D. V., Herbert, T. T. (1999). The genesis of entrepreneurship. Entrepreneurship Theory and Practice, 23(3): 29-45.

11. Brockhaus, R.H. (1980). Risk Taking Propensity of Entrepreneurs. The Academy of Management Journal, 23(3): 509-520.

12. Brockhaus, R.H. (1987). Entrepreneurial folklore. Journal of Small Business Management, 25(3): 1-6.

13. Carr, J.C., Sequeira, J.M. (2007). Prior family business exposure as intergenerational influence and entrepreneurial intent: a theory of planned behaviour approach. Journal of Business Research, 60(10): 1090-1098.

14. Carree, M. A., Thurik, A. R. (2003). The Impact of Entrepreneurship on Economic Growth. In: Audretsch, D. B., Z. J. Acs (eds.): Handbook of Entrepreneurship Research. Boston/Dordrecht: Kluwer Academic Publishers, 437-471.

15. Cheng, M.Y., Chan, W.S., Mahmood, A. (2009). The effectiveness of entrepreneurship education in Malaysia. Education + Training, 51(7): 555-566.

16. Crant, J.M. (1996). The Proactive Personality Scale as a Predictor of Entrepreneurial Intentions. Journal of Small Business Management, 34(3): 42-49.

17. Dabić, M., Daim, T., Bayraktaroglu, E., Novak, I., Bašić, M. (2012). Exploring gender differences in attitudes of university students towards entrepreneurship: An international survey. International Journal of Gender and Entrepreneurship, 4(3): 316-336.

18. Davidsson, P. (1995). Culture, structure and regional levels of entrepreneurship. Entrepreneurship and Regional Development, 7(1): 41-62. 
19. Debarliev, S., Janeska-Iliev, A., Bozhinovska, T., Ilieva, V. (2015). Antecedents of entrepreneurial intention: Evidence from Republic of Macedonia. BEH Business and Economic Horizons, 11(3): 143-161.

20. De Clercq, D., Benson, H., Martin, B. (2012). The roles of learning orientation and passion for work in the formation of entrepreneurial intention. International Small Business Journal, 31(6): 652-676.

21. De Pillis, E., Reardon, K.K. (2007). The influence of personality traits and persuasive messages on entrepreneurial intention: a cross-cultural comparison. Career Development International,12(4): 382-396.

22. Dézsi-Benyovszki, A., Szabó, T.P. (2017). Intrapreneurs and Entrepreneurs Do They Differ in Romania? Acta Oeconomica, 67 (1): 43-61.

23. Elfving, J., Brännback, M. and Carsrud, A.L. (2009), 'Toward a contextual model of entrepreneurial intents”, in: Carsrud, A.L. and Brännback, M. (eds.), Understanding the Entrepreneurial Mind, New York: Springer, p 23-34.

24. Engle, R.L., Dimitriadi, N., Gavidia, J.V., Schlaegel, C., Delanoe, S., Alvarado, I., He, X., Buame, S., Wolff, B. (2010). Entrepreneurial intent: a twelve-country evaluation of Ajzen's model of planned behaviour. International Journal of Entrepreneurial Behaviour and Research, 16(1): 36-58.

25. Erken, H., Donselaar, P., Thurik, A. R. (2016). Total factor productivity and the role of entrepreneurship. The Journal of Technology Transfer, online first: $1-29$.

26. Erzsébet, K. (2004). The Role of Education and Training in the Process of Building an Entrepreneurial Society in Hungary. Society and Economy, 26(1): 127-139.

27. European Commission. (2013). Entrepreneurship in the EU and Beyond. Flash Eurobarometer 354. Brussels: European Commission. Retrieved from https:// data.europa.eu/euodp/hr/data/dataset/S765_283

28. Eurostat. (2015). People in the EU: who are we and how do we live? Luxembourg: European Union.

29. Fayolle, A., Gailly, B., Lassas-Clerc, N. (2006). Assessing the impact of entrepreneurship education programmes: a new methodology. Journal of European Industrial Training, 30(9): 701-720.

30. Freytag A., Thurik, A.R. (2007). Entrepreneurship and its determinants in a cross-country setting. Journal of Evolutionary Economics, 17(2): 117-131.

31. Gartner, W.B., Shaver, K.G., Gatewood, E., Katz, J.A. (1994). Finding the entrepreneur in entrepreneurship. Entrepreneurship Theory and Practice, 18(3): 5-9.

32. GEM National Team for Macedonia. (2013). Entrepreneurship in Macedonia. Macedonian Enterprise Developing Foundation. $4^{\text {th }}$ Research. 
T. JOVANOV APASIEVA, E. RAJH, J. BUDAK, LJ. DAVČEV: Entrepreneurial intentions of students at private... EKONOMSKI PREGLED, 72 (2) 157-184 (2021)

33. Grilo I., Thurik, A. R. (2005). Latent and actual entrepreneurship in Europe and the US: some recent developments. International Entrepreneurship and Management Journal, 1(4): 441-459.

34. Grilo, I., Thurik, A.R. (2008). Determinants of entrepreneurial engagement levels in Europe and the US. Industrial and Corporate Change, 17(6): 11131145.

35. Harris, M.L., Gibson, S.G. (2008). Examining the entrepreneurial attitudes of US business students. Education + Training, 50(7): 568-581.

36. Hisrich, R.D., Peters, M.P. (1995). Entrepreneurship: Starting, Developing, and Managing a New Enterprise. Chicago: Irwin.

37. Iakovleva, T., Kolvereid, L., Stephan, U. (2011). Entrepreneurial intentions in developing and developed countries. Education and Training, 53(5): 353-370.

38. Jurasić, D. (2016). Studiraju najviše djeca visoko obrazovanih roditelja, a šanse djeci siromašnih i niskoobrazovanih gotovo nikakve. VecernjiList. Retrieved from https://www.vecernji.hr/vijesti/studij-pohada-manje-od-10-posto-djececiji-roditelji-nisu-visokoobrazovani-1128223

39. Kedmenec, I., Oreški, D., Vuković, K., Postolov, K., Jovanovski, K. (2017). Decision tree modeling for entrepreneurial intention. In: Vopava, J., Douda, V., Kratochvil, R., Konecki, M. (eds): Proceedings of the $11^{\text {th }}$ MAC 2017 International Conference. Prague: MAC Prague Consulting s.r.o., 161-170.

40. Kedmenec, I., Rebernik, M., Perić, J. (2015). The Impact Of Individual Characteristics On Intentions To Pursue Social Entrepreneurship. Ekonomski pregled, 66(2), 119-137.

41. Kickul, J., Gundry, L.K., Barbosa, S.D., Whitcanack, L. (2009). Intuition versus analysis? Testing differential models of cognitive style on entrepreneurial self-efficacy and the new venture creation process. Entrepreneurship Theory and Practice, 33(2): 439-453.

42. Kolvereid, L. (1996). Prediction of employment status choice intentions. Entrepreneurship Theory and Practice, 21(1): 47-57.

43. Kolvereid, L., Isaksen, E. (2006). New business start-up and subsequent entry into self-employment. Journal of Business Venturing, 21(6): 866-885.

44. Kristiansen, S., Indarti, N. (2004). Entrepreneurial Intention among Indonesian and Norwegian students. Journal of Enterprising Culture, 12(1): 55-78.

45. Krueger, N.F. (1993). The impact of prior entrepreneurial exposure on perceptions of new venture feasibility and desirability. Entrepreneurship Theory and Practice, 18(1): 5-21.

46. Krueger, N.F., Brazeal D.V. (1994). Entrepreneurial potential and potential entrepreneurs. Entrepreneurship Theory and Practice, 18(3): 91-104. 
47. Krueger, N.F., Carsrud, A.L. (1993). Entrepreneurial intentions: applying the theory of planned behaviour. Entrepreneurship and Regional Development, 5(4): 315-330.

48. Krueger, N.F., Reilly, M.D., Carsrud, A.L. (2000). Competing models of entrepreneurial intentions. Journal of Business Venturing, 15(5-6): 411-432.

49. Kutner, M.H., Nachtsheim, C.J., Neter, J. (2004). Applied linear regression models. Boston: Mcgraw Hill/Irwin.

50. Kuckertz, A. (2013). What's hot in entrepreneurship research 2013? Stuttgart: University of Hohenheim.

51. Kuckertz, A., Prochotta, A. (2018). What's hot in entrepreneurship research 2018? Stuttgart: University of Hohenheim.

52. Langer, J., Alfirević, N., Pavičić, J., Krneta, M. (2016). Intentions and Perceptions of the Entrepreneurial Career Among Croatian Students: Initial Results of a Longitudinal Empirical Study. In: Bögenhold, D., Bonnet, J., Dejardin, M., Garcia Pérez de Lema, D. (eds): Contemporary Entrepreneurship. Cham: Springer International Publishing, 213-228.

53. Lee, L., Wong. P.K., Foo, M.D., Leung, A. (2011). Entrepreneurial intentions: The influence of organizational and individual factors. Journal of Business Venturing, 26(1): 124-136.

54. Lee, S.H., Wong, P.K. (2004). An exploratory study of technopreneurial intentions: a career anchor perspective. Journal of Business Venturing, 19(1): 7-28.

55. Lilek, M. (2015). U Hrvatskoj ima 30-ak privatnih učilišta, a nijedno se ne sufinancira. Jutarnji List. Retrieved from http://izbori.jutarnji.hr/u-hrvatskojima-30-ak-privatnih-ucilista-a-nijedno-se-ne-sufinancira/

56. Liñán, F., Fayolle, A. (2015). A systematic literature review on entrepreneurial intentions: citation, thematic analyses, and research agenda. International Entrepreneurship and Management Journal, 11(4): 907-933.

57. Liñán, F., Santos, F. J. (2007). Does social capital affect entrepreneurial intentions? International Advances in Economic Research, 13(4): 443-453.

58. Liñán, F., Chen, Y.W. (2009). Development and cross-cultural application of a specific instrument to measure entrepreneurial intentions. Entrepreneurship Theory and Practice, 33(3): 593-617.

59. Liñán, F., Rodríguez-Cohard, J.C., Rueda-Cantuche, J.M. (2005). Factors affecting entrepreneurial intention levels. 45th Congress of the European Regional Science Association: Land Use and Water Management in a Sustainable Network Society. Amsterdam: European Regional Science Association (ERSA).

60. Liñán F., Santos F.J., Fernández J. (2011). The influence of perceptions on potential entrepreneurs. International Entrepreneurship and Management Journal, 7(3): 373-390. 
T. JOVANOV APASIEVA, E. RAJH, J. BUDAK, LJ. DAVČEV: Entrepreneurial intentions of students at private...

61. Lope Pihie, Z.A., Bagheri, A. (2009). Entrepreneurial intention of university students: An analysis of gender and ethnic groups. The International Journal of Knowledge, Culture and Change Management, 9(4): 49-59.

62. Lumpkin, J.R. (1985). Validity of a Brief Locus of Control Scale for Survey Research. Psychological Reports, 57(2): 655-659.

63. Lüthje, C., Franke, N. (2003). The 'making' of an entrepreneur: Testing a model of entrepreneurial intent among engineering students at MIT. $R \& D$ Management, 33(2):135-147.

64. Macura, R., Konda, I., Končar, M. (2015). The entrepreneurial desirability within students' intentions: Bosnia and Herzegovina case study. Actual Problems of Economics, 168(6): 293-304.

65. Mastura, J., Rashid, A., Aziz, A. (2008). Entrepreneurship education in developing country: Exploration on its necessity in the construction programme. Journal of Engineering, Design and Technology, 6(2): 178-189.

66. Matlay, H. (2006). Researching entrepreneurship and education part 2: what is entrepreneurship education and does it matter? Education + Training, 48(8-9): 704-718.

67. Morić Milovanović, B., Srhoj, S., Krišto T. (2015a). Modeliranje poduzetničkih namjera studenata i studentica Sveučilišta u Zagrebu. Zbornik Ekonomskog fakulteta u Zagrebu, 13(2): 17-47.

68. Morić Milovanović, B., Krišto T., Srhoj, S. (2015b). Što razlikuje studente $\mathrm{s}$ poduzetničkim namjerama? Analiza empirijskog modela odrednica poduzetničkih namjera među studentima sveučilišta u Zagrebu. Ekonomska misao i praksa, 24(1): 51-170.

69. Obadić, A. (2017). Nezaposlenost mladih I usklađenost obrazovnog sustava s potrebama tržišta rada. Ekonomska misao i praksa, 26(1): 129-150.

70. Parker, S. C. (2011). Intrapreneurship or Entrepreneurship? Journal of Business Venturing, 26(1): 19-34.

71. Peng, Z., Lu, G., Kang, H. (2012). Entrepreneurial Intentions and Its Influencing Factors: A Survey of the University Students in Xi'an China. Creative Education, 3(8): 95-100.

72. Pennings, J., Kimberly, J. (1997). Environmental influences on the creation process. In: Miles, R. (eds): The Organizational Life Cycle. Issues in the Creation, Transformation, and Decline of Organizations. San Francisco: Jossey -Bass, 135-160.

73. Pejić Bach M., Aleksić A., Merkač-Skok M. (2018). Examining determinants of entrepreneurial intentions in Slovenia: applying the theory of planned behaviour and an innovative cognitive style, Economic Research-Ekonomska istraživanja, 31(1), 1453-1471. 
74. Pfeifer, S., Šarlija, N., Zekić Sušac, M. (2016). Shaping the Entrepreneurial Mindset: Entrepreneurial Intentions of Business Students in Croatia. Journal of Small Business Management, 54(1): 102-117.

75. Rajh, E., Budak, J., Ateljević, J., Davčev, Lj. Jovanov, T., Ognjenović, K. (2017). Entrepreneurial intentions in selected South-East European countries. In: Ateljević, J. (eds): Conference Proceedings: Economic development and entrepreneurship in transition economies: is free trade working for transitional and developing economies? Banja Luka: Faculty of Economics, 592-610.

76. Rotter, J.B. (1966). Generalized expectancies for internal versus external control of reinforcement. Psychological Monographs, 80(1): 1-28.

77. Schlaegel, C., Koenig, M. (2014). Determinants of Entrepreneurial Intent: A Meta-Analytic Test and Integration of Competing Models. Entrepreneurship Theory and Practice, 38(2): 291-332.

78. Segal, G., Borgia, D., Schoenfeld, J. (2005). The motivation to become an entrepreneur. International Journal of Entrepreneurial Behaviour and Research, 11(1): 42-57.

79. Shane, S., Venkataraman, S. (2000). The Promise of Entrepreneurship as a Field of Research. The Academy of Management Review, 25(1): 217-226.

80. Shapero, A. (1984). The entrepreneurial event. In: Kent, C.A. (eds): The environment for entrepreneurship. Lexington: Lexington Books.

81. Shapero, A., Sokol, L. (1982): Social dimensions of entrepreneurship. In: Kent, C.A., Sexton, D.L., Vesper, K.H. (eds): Encyclopedia of entrepreneurship. Englewood Cliffs: Prentice Hall, 72-90.

82. Shook, C.L., Bratianu, C. (2010). Entrepreneurial intent in a transitional economy: An application of the theory of planned behaviour to Romanian students. International Entrepreneurship and Management Journal, 6(3): 231-247.

83. Storey, D. J. (2003): Entrepreneurship and Public Policies. In:Audretsch Z. J., Acs, D. B. (eds): Handbook of Entrepreneurship Research. Boston/Dordrecht: Kluwer Academic Publishers, 473-511.

84. Tomovska Misoska, A., Dimitrova, M., Mrsik, J. (2016). Drivers of entrepreneurial intentions among business students in Macedonia. Economic Research-Ekonomska Istraživanja, 29(1): 1062-1074.

85. Tkachev, A., Kolvereid, L. (1999): Self-employment intentions among Russian students. Entrepreneurship and Regional Development, 11(3): 269-280.

86. Van Praag, M., Van Witteloostuijn, A., Van Der Sluis, J. (2009). Returns for Entrepreneurs vs. Employees: The Effect of Education and Personal Control on the Relative Performance of Entrepreneurs vs. Wage Employees. IZA Discussion Paper, No. 4628. 
T. JOVANOV APASIEVA, E. RAJH, J. BUDAK, LJ. DAVČEV: Entrepreneurial intentions of students at private...

87. Veciana, J.M.,Aponte, M., Urbano, D. (2005). University students' attitudes towards entrepreneurship: a two countries comparison. International Entrepreneurship and Management Journal, 1(2): 165-182.

88. Verheul, I., Thurik, R., Grilo, I., Zwan, Pvd. (2012). Explaining preferences and actual involvement in self-employment: Gender and the entrepreneurial personality. Journal of Economic Psychology,33: 325-341.

89. Watchravesringkan, K.T., Hodges, N.N., Yurchisin, J., Hegland, J., Karpova, E., Marcketti, S.,Yan, R. (2013). Modelling entrepreneurial career intentions among undergraduates: An examination of the moderating role of entrepreneurial knowledge and skills. Family and Consumer Sciences Research Journal, 41(3): 325-342.

90. World Bank. (2016). Doing Business 2016: Measuring Regulatory Quality and Efficiency. Washington. DC: World Bank.

91. Zellweger, T., Sieger, P., Halter, F. (2011). Should I stay or should I go? Career choice intentions of students with family business background. Journal of Business Venturing, 26: 521-536.

92. Zhao, H., Seibert, S.E., Hills, G.E. (2005). The mediating role of self-efficacy in the development of entrepreneurial intentions. Journal of Applied Psychology, 90(6): 1265-1272. 


\section{Appendix: Questionnaire}

\section{Dear Student,}

We conduct the research on students' attitudes and opinions. Your participation in the survey is highly appreciated and would contribute to the success of our research. The questionnaire is entirely anonymous and the survey is conducted for scientific purposes only.

1. To which extend you agree or do not agree with each of the following statements? Please circle only one answer for every statement on the scale from 1 to 5 .

$1=$ Strongly disagree, $2=$ Disagree, $3=$ Neither agree nor disagree, $4=$ Agree, $5=$ Strongly agree.

\begin{tabular}{|c|c|c|c|c|c|c|}
\hline 1 & $\begin{array}{l}\text { When I make plans, I am almost certain that I can } \\
\text { make them work }\end{array}$ & 1 & 2 & 3 & 4 & 5 \\
\hline 2 & $\begin{array}{l}\text { Getting people to do the right things depends upon } \\
\text { ability; luck has nothing to do with it. }\end{array}$ & 1 & 2 & 3 & 4 & 5 \\
\hline 3 & What happens to me is my own doing. & 1 & 2 & 3 & 4 & 5 \\
\hline 4 & $\begin{array}{l}\text { Many of the unhappy things in people's lives are partly } \\
\text { due to bad luck. }\end{array}$ & 1 & 2 & 3 & 4 & 5 \\
\hline 5 & $\begin{array}{l}\text { Getting a good job depends mainly on being in the } \\
\text { right place at the right time. }\end{array}$ & 1 & 2 & 3 & 4 & 5 \\
\hline 6 & $\begin{array}{l}\text { Many times I feel that I have little influence over the } \\
\text { things that happen to me. }\end{array}$ & 1 & 2 & 3 & 4 & 5 \\
\hline 7 & When I travel I tend to use new routes. & 1 & 2 & 3 & 4 & 5 \\
\hline 8 & $\begin{array}{l}\text { I like to try new things (e.g. exotic food or going to new } \\
\text { places). }\end{array}$ & 1 & 2 & 3 & 4 & 5 \\
\hline 9 & I have taken a risk in the last six months. & 1 & 2 & 3 & 4 & 5 \\
\hline 10 & $\begin{array}{l}\text { Banks in Croatia do not readily give credits to start-up } \\
\text { companies. }\end{array}$ & 1 & 2 & 3 & 4 & 5 \\
\hline 11 & $\begin{array}{l}\text { State laws (rules and regulations) are adverse to } \\
\text { running a company. }\end{array}$ & 1 & 2 & 3 & 4 & 5 \\
\hline 12 & $\begin{array}{l}\text { It is hard to find a business idea for a business that } \\
\text { hasn't been realized before. }\end{array}$ & 1 & 2 & 3 & 4 & 5 \\
\hline 13 & $\begin{array}{l}\text { Entrepreneurs have a positive image within Croatian } \\
\text { society. }\end{array}$ & 1 & 2 & 3 & 4 & 5 \\
\hline 14 & $\begin{array}{l}\text { Qualified consultant and service support for new } \\
\text { companies is available in Croatia. }\end{array}$ & 1 & 2 & 3 & 4 & 5 \\
\hline
\end{tabular}


T. JOVANOV APASIEVA, E. RAJH, J. BUDAK, LJ. DAVČEV: Entrepreneurial intentions of students at private... EKONOMSKI PREGLED, 72 (2) 157-184 (2021)

\begin{tabular}{|c|c|c|c|c|c|c|}
\hline 15 & $\begin{array}{l}\text { The creative atmosphere in the society inspires to } \\
\text { develop ideas for new businesses. }\end{array}$ & 1 & 2 & 3 & 4 & 5 \\
\hline 16 & $\begin{array}{l}\text { Being an entrepreneur implies more advantages than } \\
\text { disadvantages. }\end{array}$ & 1 & 2 & 3 & 4 & 5 \\
\hline 17 & A career as entrepreneur is attractive for me. & 1 & 2 & 3 & 4 & 5 \\
\hline 18 & $\begin{array}{l}\text { If I had the opportunity and resources, I'd like to start } \\
\text { a firm. }\end{array}$ & 1 & 2 & 3 & 4 & 5 \\
\hline 19 & $\begin{array}{l}\text { Being an entrepreneur would entail great satisfactions } \\
\text { for me. }\end{array}$ & 1 & 2 & 3 & 4 & 5 \\
\hline 20 & $\begin{array}{l}\text { Among various options, I would rather be an } \\
\text { entrepreneur. }\end{array}$ & 1 & 2 & 3 & 4 & 5 \\
\hline 21 & $\begin{array}{l}\text { To start a firm and keep it working would be easy for } \\
\text { me. }\end{array}$ & 1 & 2 & 3 & 4 & 5 \\
\hline 22 & I am prepared to start a viable firm. & 1 & 2 & 3 & 4 & 5 \\
\hline 23 & I can control the creation process of a new firm. & 1 & 2 & 3 & 4 & 5 \\
\hline 24 & I know the necessary practical details to start a firm. & 1 & 2 & 3 & 4 & 5 \\
\hline 25 & I know how to develop an entrepreneurial project. & 1 & 2 & 3 & 4 & 5 \\
\hline 26 & $\begin{array}{l}\text { If I tried to start a firm, I would have a high probability } \\
\text { of succeeding. }\end{array}$ & 1 & 2 & 3 & 4 & 5 \\
\hline 27 & I am ready to do anything to be an entrepreneur. & 1 & 2 & 3 & 4 & 5 \\
\hline 28 & My professional goal is to become an entrepreneur. & 1 & 2 & 3 & 4 & 5 \\
\hline 29 & I will make every effort to start and run my own firm. & 1 & 2 & 3 & 4 & 5 \\
\hline 30 & I am determined to create a firm in the future. & 1 & 2 & 3 & 4 & 5 \\
\hline 31 & I have very seriously thought of starting a firm. & 1 & 2 & 3 & 4 & 5 \\
\hline 32 & I have the firm intention to start a firm some day. & 1 & 2 & 3 & 4 & 5 \\
\hline 33 & $\begin{array}{l}\text { If I decided to create a firm, my close family would } \\
\text { approve it. }\end{array}$ & 1 & 2 & 3 & 4 & 5 \\
\hline 34 & $\begin{array}{l}\text { If I decided to create a firm, my friends would approve } \\
\text { it. }\end{array}$ & 1 & 2 & 3 & 4 & 5 \\
\hline 35 & $\begin{array}{l}\text { If I decided to create a firm, my colleagues would } \\
\text { approve it. }\end{array}$ & 1 & 2 & 3 & 4 & 5 \\
\hline
\end{tabular}

2. Please note your gender, age, and the year of study you are enrolled to.

\begin{tabular}{|l|llllll|}
\hline D1 & Gender & & & M & & F \\
\hline D2 & Age & & & & & \\
\hline D3 & Study year & 1 & 2 & 3 & 4 & \\
\hline
\end{tabular}




\title{
PODUZETNIČKE NAMJERE STUDENATA PRIVATNIH SVEUČILIŠTA U TRANZICIJSKIM ZEMLJAMA
}

\begin{abstract}
Sažetak
U radu se ispituje poduzetnički potencijal studenata privatnih sveučilišta u dvije tranzicijske zemlje analizom poduzetničkih namjera studenata. Empirijska analiza se temelji na anketnim podacima prikupljenima 2017. i 2018. godine na više od 400 studenata ekonomije i poslovne ekonomije na privatnim sveučilištima u Sjevernoj Makedoniji i Hrvatskoj. Koristi se teorija planiranog ponašanja i niz determinanti kako bi se istražio utjecaj individualnih i kontekstualnih varijabli na poduzetničke namjere. Sagledavanje slike o poduzetništvu koju studenti imaju i njihove ocjene socio-ekonomske uloge poduzetnika u društvu i prestižnosti u odnosu na druga zanimanja, daje vrijedne rezultate za nositelje politike koji žele unaprijediti poduzetnički potencijal i poslovnu klimu u manje razvijenim zemljama. Rad iznosi empirijske dokaze o pozitivnim učincima dvije varijable iz teorije planiranog ponašanja na poduzetničke namjere, a to su osobni stavovi studenata poslovne ekonomije na privatnim sveučilištima u tranzicijskim zemljama prema poduzetništvu i subjektivne norme. Najzanimljiviji je rezultat pozitivan učinak percipiranih prepreka kao kontekstualne varijable na poduzetničke namjere, što je u suprotnosti s dosadašnjim spoznajama.
\end{abstract}

Ključne riječi: poduzetništvo, poduzetničke namjere, tranzicija, teorija planiranog ponašanja 